\title{
The Effect of Parenteral Infusion of Amino Acids in Burn Patient
}

\author{
Nahar $\mathrm{K}^{1}$, Naher ZU², Khanam $\mathrm{M}^{3}$, Akhter $\mathrm{S}^{4}$, Bashar $\mathrm{T}^{5}$, Arslan $\mathrm{MI}^{6}$
}

\begin{abstract}
Adequate nutritional support may prevent weight loss following severe burn injury. However, persistently low levels of serum albumin, transferring and serum total protein in burn patients have suggested that a protein deficiency may continue to exist which is out of proportion to energy requirements.
\end{abstract}

This interventional study cross sectional study was done in the Department of Biochemistry, Bangabandhu Sheikh Mujib Medical University (BSMMU), Dhaka, Bangladesh during January 2008 to December 2008. A total of 40 acute burn injury (within 24 hours of burn) patients of 20-45 years age with 15\%-30\% burn were selected for this study as case. The study subjects were divided into two groups: Group I represent superficial burn \& Group II represents deep burn.

The mean age of $28.35 \pm 6.81$ years and $30.85 \pm 7.32$ years in group I and group II respectively. The number of male in Group-I was 08 and Group-II was 08 and male female ratio was 2:3. The mean serum total protein before infusion of amino acid in Group-I was 55.31 $\pm 3.58 \mathrm{~g} / \mathrm{L}$ and in Group-II was $52.01 \pm 2.26 \mathrm{~g} / \mathrm{L}(p<0.001)$. The mean serum total protein after infusion of amino acid in Group-I was $68.02 \pm 2.04 \mathrm{~g} / \mathrm{L}$ and in Group-II was $61.86 \pm 2.49 \mathrm{~g} / \mathrm{L}$ $(p<0.001)$. The mean serum albumin before infusion of amino acid in Group-I was 27.6 $\pm 2.88 \mathrm{~g} / \mathrm{L}$ and in Group-II was $25.57 \pm 1.89 \mathrm{~g} / \mathrm{L}(\mathrm{p}<0.001)$. The mean serum albumin after infusion of amino acid in Group-I was 22.29 $\pm 3.50 \mathrm{~g} / \mathrm{L}$ and in Group-II was $19.83 \pm 2.86 \mathrm{~g} / \mathrm{L}(\mathrm{p}<0.001)$. In group-I, serum total protein was increased by $22.98 \%$ after infusion and in group-II, that was increased by $18.94 \%(p<0.01)$.

01. Dr. Kamrun Nahar

Consultant, Biochemistry Department of Burn Unit

Dhaka Medical College, Dhaka

02. Corresponding Author: Dr. Zeba-un-Naher

Medical Officer, Department of Biochemistry

Bangabandhu Sheikh Mujib Medical University, Dhaka

03. Dr. Matira Khanam

Assistant Professor, Department of Pharmacology \& Therapeutics

Ibn Sina Medical College, Dhaka

04. Dr. Shaheen Akhter

Lecturer of Biochemistry

Shaheed Suhrawardy Medical College, Dhaka

05. Dr. Tahmina Bashar

Research Assistant, Department of Pharmacology,

Bangabandhu Sheikh Mujib Medical University, Dhaka

06. Professor M. Iqbal Arslan

Professor \& Chairman, Department of Biochemistry,

Bangabandhu Sheikh Mujib Medical University, Dhaka
In group-I, serum albumin was decreased by $19.24 \%$ after infusion and in group-II, that was decreased by $22.45 \%$ $(p<0.05)$. Serum total protein significantly increased after infusion of amino acid but serum albumin significantly decreased after infusion of amino acid.

Key word: Serum total protein, serum albumin, infusion of amino acid.

\section{Introduction}

A burn is an injury caused by heat, cold, electricity, chemicals, light, radiation, or friction. Burn is one of the top five causes of fatal injuries to people ${ }^{1}$. Prevalence of burn injury is very high in Bangladesh though exact statistics is not available. Chemical burns like throwing acids by culprits are common in Bangladesh ${ }^{2}$. Burn cause not only physical injury but psychological abnormality. Symptoms of depression are highly prevalence in burn reconstruction patients ${ }^{3}$.

A well-described array of metabolic derangements occurs after burn. Defects of both cellular and humoral immune function increase the likelihood of infection ${ }^{4}$. Metabolic response to stress could lead to malnutrition, which will worsen the stress situation by increasing the patient's susceptibility to infection ${ }^{5}$. Infection is the most common cause of death in hospitalized burn patients. This is associated with a variety of documented immunologic abnormalities. Many immunologic functions are dependent upon optimal availability of specific amino acids, and that routine diets do not provide sufficient protein to satisfy the needs of seriously burned individuals ${ }^{6}$.

Burns and sepsis have in common a rapid net catabolism of body protein, as well as a redistribution of the nitrogen pool within the body. Provision of dietary protein and/or amino acids is essential for maintaining net protein catabolism. Furthermore, it seems likely that a higher-than-normal intake of protein may be useful. Even the mild stress of simple bed rest increases the protein requirement to maintain nitrogen balance. Branched chain amino acids (BCAAs) possess regulatory properties on protein metabolism. Prospective controlled trials of BCAA supplementation in septic patients demonstrated an improvement in patients' nutritional status and outcome. A catabolic insult like burn induces a marked generalized net protein catabolism in the muscle. This accelerated protein breakdown is associated with inhibited uptake of amino acids (AAs) by the muscles, leading to an increased flux of amino acids from the periphery to the liver ${ }^{5}$.

In parallel, hepatic uptake of AAs is stimulated and protein synthesis and gluconeogenesis in the liver are enhanced. The alterations in nitrogen and protein metabolism present a major threat for the patient, as demonstrated by the 
relationship between loss of lean body mass and morbidity or mortality. Therefore, a therapy able to promote protein anabolism or slow down protein degradation would constitute a major step forward ${ }^{5}$. Supplementation with glutamine dipeptide was associated with enhanced glutamine plasma concentrations, decreased gut permeability and endotoxin levels as well as wound healing time and lower cost of hospitalization ${ }^{7}$.

Alexander $(1980)^{6}$ showed that serum total protein was significantly higher $(\mathrm{p}<0.0002)$ in children who took higher high protein diet. Though the serum albumin was higher in high protein diet group, it did not reach the significant level. EI-Gallal and Yousef $(2002)^{8}$ found that the mean value of total protein of patients supplemented with parenteral amino acids remained at nearly normal level $(6.21 \mathrm{gm} / \mathrm{dl})$ compared with that of patients without parenteral amino acids supplement (only enteral nutrition), the difference was statistically significant $(\mathrm{p}<0.05)$. The authors showed that parenteral supplementation with enteral nutrition is safe, gives better results in minimizing the negative nitrogen balance and to a great extent preserves the nutritional integrity of severely burned patients ${ }^{8}$. This interventional study on amino acid supplementation in burn patient was carried out to find out to compare between total protein and albumin in burn and deep burn before and after infusion of amino acid.

\section{Materials and Methods}

This interventional study on amino acid supplementation in burn patient was carried out in the Department of Clinical Pathology, Internal Medicine (Unit-III), Outpatient Department of Department of Biochemistry, Bangabandhu Sheikh Mujib Medical University (BSMMU), Dhaka, Bangladesh, during the period from January 2008 to December 2008. This study included burn patient of 20-45 years of age, both sexes and patients with burn of 15-30\% body surface area in the above mentioned hospital during the study period. Burn patients with other co-morbid conditions such as diabetes mellitus, hypertension, renal impairment, hepatic diseases or malnutrition were excluded from the study.

An informed written consent was taken from all the study subjects to participate into the study. After admission of patients with acute burn injury, they were advised to take same quality of oral diet during the study period. Then blood sample for serum total protein and albumin will be taken on 1st and 2nd day of admission. Then they were infused 500 $\mathrm{ml}$ of amino acid (prosol i.v.) on 2nd day to 6th day of burn. Blood sample for total protein and albumin were further taken 48 hours after last infusion of amino acid (8th day of burn). Blood was transferred immediately into a dry, clean plastic test tube with a gentle push to avoid hemolysis. Collected blood was allowed to clot \& then centrifuged. Separated serum was collected into plastic micro centrifuged tube \& appropriately labeled which was used for estimation of total protein and albumin. All the values were recorded in a data collection sheet (questionnaire). Statistical Analysis: Continuous data were expressed as mean \pm SD. Statistical analysis were performed by using "Statistical Package for
Social Sciences (SPSS)," for window version-16.0.

Data were analyzed by paired t-test, unpaired t-test, proportion test and Chi square test using Statistical Package for Social Sciences (SPSS)window version.

\section{Results}

The mean age was $28.35 \pm 6.81$ years in group I and that of Group-II was $30.85 \pm 7.32$ years. No significant difference ( $>0.05)$ was found between two group regarding mean age distribution. Male patient was $40.0 \%$ in Group-I and $40.0 \%$ in Group-II. Male female ratio was 2:3.

The mean serum total protein of the study subjects before infusion of amino acid was $53.66 \pm 3.39 \mathrm{~g} / \mathrm{L}$ and after infusion was $64.94 \pm 3.85 \mathrm{~g} / \mathrm{L}$. The mean serum albumin of the study subjects before infusion was $26.59 \pm 2.61 \mathrm{~g} / \mathrm{L}$ and after infusion was $21.06 \pm 3.39 \mathrm{~g} / \mathrm{L}$. The mean difference of serum total protein and serum albumin were significant $(\mathrm{p}<0.001)$ (Table I).

Table I: Comparison of serum total protein and serum albumin before and after infusion of amino acid of the study subjects.

\begin{tabular}{|l|l|l|l|l|}
\hline $\begin{array}{l}\text { No. of study } \\
\text { subjects }\end{array}$ & $\begin{array}{l}\text { Before infusion } \\
(\mathrm{n}=40) \\
(\mathrm{Mean} \pm \mathrm{SD})\end{array}$ & $\begin{array}{l}\text { After infusion } \\
(\mathrm{n}=40) \\
(\mathrm{Mean} \pm \mathrm{SD})\end{array}$ & t value & p value \\
\hline $\begin{array}{l}\text { Total protein } \\
(\mathrm{g} / \mathrm{L})\end{array}$ & $53.66 \pm 3.39$ & $64.94 \pm 3.85$ & -22.57 & $<0.001^{*}$ \\
\hline $\begin{array}{l}\text { Serum albumin } \\
(\mathrm{g} / \mathrm{L})\end{array}$ & $26.59 \pm 2.61$ & $21.06 \pm 3.39$ & 13.39 & $<0.001^{*}$ \\
\hline
\end{tabular}

Unpaired t test was done as test of significant.* Significant

The mean serum total protein before infusion of amino acid was $55.31 \pm 3.58 \mathrm{~g} / \mathrm{L}$ and $52.01 \pm 2.26 \mathrm{~g} / \mathrm{L}$ in group I and group II respectively. The mean serum total protein after infusion of amino was $68.02 \pm 2.04 \mathrm{~g} / \mathrm{L}$ in group-I and $61.86 \pm 2.49 \mathrm{~g} / \mathrm{L}$ in group II. There were significant difference $(\mathrm{p}<0.001)$ between two groups before and after infusion of amino (Table II).

Table II: Comparison of serum total protein and serum albumin between two groups before infusion of amino acid of the study subjects.

\begin{tabular}{|l|c|c|c|c|}
\hline $\begin{array}{l}\text { Before infusion } \\
\text { of amino acid }\end{array}$ & $\begin{array}{l}\text { Superficial } \\
\text { burn (n=20) } \\
\text { (Mean } \pm \text { SD) }\end{array}$ & $\begin{array}{l}\text { Deep burn } \\
(\mathrm{n}=20) \\
(\text { Mean } \pm \text { SD) }\end{array}$ & t value & p value \\
\hline $\begin{array}{l}\text { Total protein } \\
(\mathrm{g} / \mathrm{L})\end{array}$ & $55.31 \pm 3.58$ & $52.01 \pm 2.26$ & 3.49 & $<0.001^{*}$ \\
\hline $\begin{array}{l}\text { Serum albumin } \\
(\mathrm{g} / \mathrm{L})\end{array}$ & $68.02 \pm 2.04$ & $61.86 \pm 2.49$ & 8.57 & $<0.001^{*}$ \\
\hline
\end{tabular}

Unpaired t test was done as test of significant.* Significant

The mean serum albumin before infusion of amino acid was $27.6 \pm 2.88 \mathrm{~g} / \mathrm{L}$ in Group-I and $25.57 \pm 1.89 \mathrm{~g} / \mathrm{L}$ in Group-II. The mean serum albumin after infusion of amino acid was $22.29 \pm 3.50 \mathrm{~g} / \mathrm{L}$ in Group-I and 19.83 $\pm 2.86 \mathrm{~g} / \mathrm{L}$ in Group-II. There were significant difference $(\mathrm{p}<0.05)$ between two groups before and after infusion of amino (Table III). 
Table III: Comparison of serum total protein and serum albumin between two groups after infusion of amino acid of the study subjects.

\begin{tabular}{|l|c|c|c|c|}
\hline $\begin{array}{l}\text { After infusion } \\
\text { of amino acid }\end{array}$ & $\begin{array}{l}\text { Superficial } \\
\text { burn(n=20) } \\
\text { (Mean } \pm \text { SD) }\end{array}$ & $\begin{array}{l}\text { Deep burn } \\
(\mathrm{n}=20) \\
(\text { Mean } \pm \text { SD) }\end{array}$ & t value & p value \\
\hline $\begin{array}{l}\text { Total protein } \\
\text { (g/L) }\end{array}$ & $27.6 \pm 2.88$ & $25.57 \pm 1.89$ & 2.63 & $<0.005^{*}$ \\
\hline $\begin{array}{l}\text { Serum albumin } \\
(\mathrm{g} / \mathrm{L})\end{array}$ & $22.29 \pm 3.50$ & $19.83 \pm 2.86$ & 2.43 & $<0.005^{*}$ \\
\hline
\end{tabular}

Unpaired t test was done as test of significant.* Significant

The percentage change of serum total protein concentration before and after infusion of amino acid between two groups were increased by $22.98 \%$ and $18.94 \%$ increased after infusion in group I and group II respectively. Similarly, the percentage change of serum albumin concentration before and after infusion of amino acid between two groups was decreased by $19.24 \%$ in group I and $22.45 \%$ in group II after infusion. There were significant difference $(\mathrm{p}<0.05)$ between two groups (Table IV).

Table IV: Change of total protein concentration and serum albumin (in percentage) before and after infusion of amino acid between two groups of study subjects.

\begin{tabular}{|c|c|cc|c|}
\hline $\begin{array}{l}\text { Change of total } \\
\text { protein concentration }\end{array}$ & $\begin{array}{l}\text { Group-I } \\
\text { Superficial } \\
\text { burn (n=20) }\end{array}$ & $\begin{array}{l}\text { Group-II } \\
\text { Deep burn } \\
(\mathrm{n}=20)\end{array}$ & z- value & p value \\
\hline $\begin{array}{c}\text { Increase of serum } \\
\text { total protein (g/L) }\end{array}$ & $22.98 \%$ & $18.94 \%$ & 3.13 & $<0.001^{*}$ \\
\hline $\begin{array}{c}\text { Decrease of Serum } \\
\text { albumin (g/L) }\end{array}$ & $19.24 \%$ & $22.45 \%$ & 2.51 & $<0.005^{*}$ \\
\hline
\end{tabular}

Proportion test ( $\mathrm{z}$ test) was done as test of significant.* Significant

\section{Discussion}

This interventional study on amino acid supplementation in burn patient was carried out to evaluate whether amino acid infusion in the study subjects increases serum total protein and serum albumin or not. The mean age was $28.35 \pm 6.81$ years and $30.85 \pm 7.32$ years in group I and group II respectively, with range from 20 to 45 years. The mean age was almost similar between two groups. Male patient was $40.0 \%$ in Group-I and $40.0 \%$ in Group-II. Male female ratio was 2:3.

Serum total protein and serum albumin were measured before and after infusion of amino acid in each study subjects. Serum total protein was significantly $(\mathrm{p}<0.001)$ increased after infusion in both group $p^{4,5,6,8,9}$.

EI-Gallal and Yousef $(2002)^{8}$ showed the mean value of total protein of patients supplemented with parenteral amino acids remained at nearly normal level $(6.21 \mathrm{gm} / \mathrm{dl})$ compared with that of patients without parenteral amino acids supplement (only internal nutrition). The difference between the mean values of the two groups was statistically significant $(\mathrm{p}<0.05)$. Finally they showed that parenteral supplementation with internal nutrition is safe, gives better results in minimizing the negative nitrogen balance and to a great extent preserves the nutritional integrity of severely burned patients. Trop $(2008)^{10}$ stated that soon after a burn, changes are observed in the concentration of the plasma proteins. These protein changes affect plasma's colloid osmotic pressure, which depends on both the concentration and the molecular size of the constituent protein molecules. The decrease in albumin concentration develops and remains, owing to an increased rate of catabolism, losses of exudates from the burn wound, and failure of anabolism to compensate for those losses. This study also revealed statistical significant $(\mathrm{p}>0.001)$ decreased level of serum albumin concentration. From the day of admission till 48 hours after last infusion. But this findings different from the study done abroad who found inverse relation. This inconsistent findings may be due to failure of supplying adequate amino acid infusion actually required for the study subjects, Dietary factors might be a one of the important factors for this inconsistent findings because this study could not ascertain the adequate amount of diet for the study subjects. Ijichi $(2003)^{11}$ stated that increase level of serum albumin in adult depends majority on oral diet but as we are developing country $\&$ most of the people are in below the average daily caloric intake, the findings could be the real picture for the country as well. It can be predicted that if dietary requirements for the burn subjects can be provided along with an. infusion we could find similar findings regarding serum albumin with other findings.

Moreover, the treatment protocol which used to apply on the studies differs from treatment protocol on our study. The basic aim of their treatment protocol is to halt or delay the catabolic state in the burn subjects, but unfortunately our protocol findings regarding serum albumin.

In conclusion, treatment protocol along with amino acids infusion \& caloric requirements through the diet should be re-evaluated in context to our country so that we can reduce post burn morbidity and mortality.

\section{References}

1. Lal P, Rahi M, Jain T and Ingle GK. Epidemiological Study of Burn injuries in a slum Community of Delhi. Indian Journal of Community Medicine 2006;3:201-203.

2. Rahman MS and Shakoor MA. Concepts in rehabilitation of burn patients. 2007;25:139-143.

3. Thombs BD, Haines JM, Bresnick MG, Russel GM, Fauerbach JA and Robert J. Depression in burn reconstruction patients: symptoms prevalence and association with body image and physical function. Gen Hosp Psychiatry 2008;29:14-20.

4. Hart DW, Wolf SE, Herndon DN, Chinkes DL, Lal SO, Obeng MK et al. Energy expenditure and caloric 
balance after burn increased feeding leads to fat rather than lean mass accretion. Annals of surgery 2002;235:152-161.

5. Bandt JP and Cynober L. Therapeutic Use of Branched-Chain Amino Acids in Burn, Trauma, and Sepsis.2006;136: 308-313.

6. Alexander JW, mac Millan BG, Stinnett JD, Ogle CK, Bozian RC, Fischer JE et al. Beneficial effects of aggressive protein feeding in severely burned children. 1980;192:505-516.

7. Zhou YP, Jiang ZM, Sun YH, He GH and Shu H. The effects of supplemental glutamine dipeptide on gut integrity and clinical outcome after major esharectomy in severe burns: a randomized, double-blind, controlled clinical trial. Science Direct-Clinical Nutrition Supplement 2004.
8. El-Gallal ARS and Yousef SM. Our experience in the nutritional support of burn patients. 2008;15:79.

9. Atiyeh BS, Gunn SW, Dibo SA, Metabolic implications of severe burn injuries and Their management: A systematic review of the literature. World J Surg, 2008;32:1857-1869.

10. Trop M, Schintler M, Spendel S and Stockenhuber A. Unhealed wounds, hypoalbuminaemia and cachexia in a burned child-where is the limit? Annals of Burns and Fire Disasters, 2008;2:59-94.

11. Ijichi $\mathrm{C}$, Matsumura $\mathrm{T}$, Tsuji $\mathrm{T}$ and Eto $\mathrm{Y}$. Branched-chain amino acids promote albumin synthesis in rat primary hep0atocytes through the mTOR signal transduction system. Biochemical and Biophysical Research Communications 2003;303:59-64. 